\title{
Detection of specific type-A antigen and specific antibody against avian influenza virus in native duck at Netrokona district of Bangladesh
}

\author{
M. M. Mafizul Islam ${ }^{1}$, Mir Rowshan Akter ${ }^{1}$, Md. Mostafizer Rahman ${ }^{1}$, Md. Atiqul Haque*1, Md. karim Uddin ${ }^{2}$ and Md Abu Sayed Khan ${ }^{3}$ \\ ${ }^{1}$ Department of Microbiology, Hajee Mohammad Danesh Science and Technology University, Dinajpur-5200, Bangladesh \\ ${ }^{2}$ Department of Medicine, Surgery and Obstetrics, Hajee Mohammad Danesh Science and Technology University, Dinajpur-5200, Bangladesh \\ ${ }^{3}$ PCF Feed Industries, 10 Clay Road, Khulna
}

*Corresponding Author: Dr. Md. Atiqul Haque, Lecturer, Department of Microbiology, Faculty of Veterinary and Animal Science, Hajee Mohammad Danesh Science and Technology University, Dinajpur-5200, Bangladesh, E-mail: rajvph@yahoo.com

\begin{abstract}
The present study was conducted on unvaccinated native ducks of different age groups to determine specific antibody titer level against Avian Influenza virus (AIV) by indirect Enzyme Linked Immunosorbent Assay (iELISA) and to detect avian influenza type A virus antigen by rapid AIV antigen test kit at Netrokona district of Bangladesh. This study showed that AIV specific antibody positive cases were 78 out of 90 blood serum samples and the highest antibody titer was 2323 and lowest antibody titer was 256 . The total $86.67 \%$ sera samples were showed positive result. The study showed that $66.66 \%$ sera sample were positive against AIV at 3-4 month of aged group and the highest, lowest and mean antibody titer were 1428, 256 and 906.3 respectively. On the other hand 78\% sera sample were positive against AIV at 5-6 month aged group and the highest, lowest and mean antibody titer were 1675,451 and 1083.6 respectively. The sera sample collected from 7-8 month aged group showed $88.9 \%$ positive and the highest, lowest and mean antibody titer were 1857,578 and 1285.5 respectively. The sera sample collected from 9-10 month of aged group showed $100 \%$ positive against AIV and the highest, lowest and mean antibody titer were 1971, 638 and 1571.5 respectively .The sera sample collected from duck of $\geq 11$ month aged group were $100 \%$ positive against AIV and the highest, lowest and mean antibody titer were 2323, 1423 and 1813.7 respectively. Tracheal and cloacal swabs from ducks with antibody titer more than 1813.778 were tested for the avian influenza type A antigen by Anigen Rapid AIV Ag test kit. The above sample showed $20 \%$ positive result. In conclusion it is evident that Avian influenza virus-specific antibody was successfully detected through commercially available Avian influenza virus antibody test kit (ELISA Kit) and the virus induced a significant antibody titer indicating the affecting virus was absolutely AIV.
\end{abstract}

Key words: Avian Influenza virus (AIV), Indirect enzyme linked immunosorbent assay (iELISA), Antibody titer, Anigen Rapid AIV antigen test kit

(C) 2013 Microbes and Health. All rights reserved

\section{Introduction}

Poultry farming is emerging as a strong agro-based industry in Bangladesh. The total poultry population, both backyard and commercial, accounts to approximately 210 million, producing 5400 million pieces of eggs annually and nearly $15 \%$ of total animal protein (Asifuddin, 2013). In fact, Bangladesh, with duck stocks of 38.1 million, has the third largest duck population in the world (Ahmed et al, 2012). Ducks are generally kept along with backyard chickens and they are intermingling with chickens during forage. The density of duck population is higher in the areas of large water bodies. The highest density of ducks is seen in north eastern region of the country. However, this sector is now facing a hazardous situation with recent outbreak of Avian Influenza (AI) posing a great threat to the growing poultry industry. Transmission risk factors include small scale commercial farm, semi-scavenging farm with poor bio-security and free-range duck flocks.

Bangladesh has experienced Highly Pathogenic Avian Influenza (HPAI) outbreaks in our domestic chiken first in early 2007 and after an initial decline the incidence reappeared in the country in late 2007 to continue till early 2008 and the country is still vulnerable to this disease (Asifuddin, 2013).

Avian influenza (AI) was recognized as a highly pathogenic viral disease of poultry caused by strains of influenza virus type A, was identified first in Italy in 1878 used to be called "fowl plague" (Lupiani and Reddy, 2009). The virus belongs to the family Orthomyxoviridae. Avian influenza is an enveloped virus with single stranded segmented RNA genome. The surface of the virion is covered with two different types of spikes or projections namely haemagglutinin (HA) and neuraminidase (NA) proteins. On the basis of the antigenicity of these glycoproteins, influenza A viruses currently cluster into sixteen $\mathrm{H}\left(\mathrm{H}_{1}-\mathrm{H}_{16}\right)$ and nine $\mathrm{N}$ $\left(\mathrm{N}_{1}-\mathrm{N}_{9}\right)$ subtypes (Islam and Giasuddin, 2007). Low pathogenic avian influenza (LPAI) viruses are frequently isolated from wild birds, especially waterfowl (Alexander, 1982) that acts as a reservoir. It has been postulated that virus is introduced into poultry by wild migrating birds (Webster et al., 2004; Alexander, 1995; Alexander and Brown, 2000).

HPAI virus may subsequently spread to other poultry farms via several routes, either via direct or indirect contact between poultry and persons during transport. Mutation from LPAI to HPAI virus occurs mainly by antigenic drift or antigenic shift (Saif et al. 2003). HPAI viruses typically produce a severe, systemic disease with high mortality in chickens and other gallinaceous birds and produce clinical signs and lesions reflecting pathophysiological damage to the respiratory, digestive and reproductive systems (Pantin et al, 2009). Ducks play an important role in the maintenance and transmission of HPAI (Henning et al, 2011). However, these same viruses usually produce no clinical signs of infection or only mild disease in domestic ducks and migratory waterfowls and the virus can survive longer without showing any clinical sign. After the 
outbreak of AI in early 2007, around 1.6 million birds were culled and disposed off. The HPAI was detected from 287 outbreaks covering 128 Upazillas, 14 Metropolitan Thana of 47 Districts. As a result of death and culling of poultry above 17,990 poultry farms were pushed out of business since July 2007 to February 2008 (Asifuddin, 2013). Influenza viruses have the ability to mutate and there are significant concerns that $\mathrm{H} 5 \mathrm{~N} 1$ virus might one day be able to infect human and spread easily from one person to another. If $\mathrm{H}_{5} \mathrm{~N}_{1}$ virus gains the capacity to spread easily from person to person, an influenza pandemic (worldwide outbreak of disease) might begin.

The present study was conducted with the following objectives:

(1) To detect the specific antibody titer level against AIV of native ducks by using indirect ELISA.

(2) To detect of avian influenza type A virus antigen by Rapid AIV Ag test kit.

\section{Materials and Methods}

The research work was conducted in the Kazi Farms Poultry Laboratoty, Gazipur, Bangladesh during the period of January to June, 2014.

\section{Collection, transportation and preparation of samples:}

For detection of antibody titer, a total of 90 blood samples were collected from the selected native duck (khaki cambel) of small scale broiler farms having average 200 duck populations situated at Netrokona Sadar and Kendua upazilla under Netrokona district of Bangladesh. The ducks were categorized into five age groups. Group A included ducks aged 3-4 month, group B included ducks aged 5-6 month, group $\mathrm{C}$ included ducks aged 7-8 month, group D included ducks aged 9-10 month and group E included ducks aged $\geq 11$ month. The blood samples were collected aseptically from the wing vein using $3 \mathrm{ml}$ disposable sterile syringe. Soon after collection of blood the syringes with blood were kept slantly at $4-8^{\circ} \mathrm{C}$ for overnight, so that blood can clot in one side of the syringe. Then the clotted blood was removed carefully with sterile needle and sera were poured into sterilized graduated centrifuge test tubes and shipped to the laboratory within 2 hours maintaining proper cooling chain in ice box. For each syringe, individual needle was used. The sera were subjected to centrifugation at $1000 \mathrm{rpm}$ for 10 minutes for purification. Then the clear sera were collected and kept in clean sterilized Eppendorf tubes and stored at $-20^{\circ} \mathrm{C}$ until performing the indirect ELISA (iELISA).

For detection of Avian Influenza (AI) antigen a total of five sample; two cloacal and three tracheal swab samples were collected aseptically from the group with highest mean antibody titer by ELISA test was tested for AI antigen.

\section{Detection of the antibody titer level}

AI antibody test kit manufactured by Proprietario e Fabricante [BioCheck (UK) Ltd.] was used for the estimation of antibody titer. The indirect enzyme-linked immunosorbent assay (iELISA) was performed according to the manufacturer's instruction using AIV pre coated plates and pre-diluted, ready to use reagents and buffer. In case of iELISA, the titer was predicted from the absorbance value of 1:500 dilution of a serum using the formula supplied with the kit. To make substrate reagent, 1 tablet was added to $5.5 \mathrm{ml}$ substrate buffer and was allowed to mix for 3 minutes or until fully dissolved. The prepared reagent was made on day of use. One wash buffer sachet was emptied and mixed into one liter of distilled water and allowed to dissolve fully by mixing. All other kit component were ready to use but were allowed to adjust the room temperature. The test samples were diluted to $1: 500$ by adding $1 \mu \mathrm{l}$ to $0.5 \mathrm{ml}$ of sample diluents. The mixture of the tube was mixed well by vortexing or shaking. The fresh Eppendorf tube was used for each separate sample. location of samples on template. $100 \mu 1$ of negative control was added into wells A1 and B1. $100 \mu$ l of positive control was added into wells $\mathrm{C} 1$ and D1. Then $100 \mu \mathrm{l}$ of diluted samples were added into the appropriate wells and the plate was covered with lid and incubated at room temperature $\left(22-27^{\circ} \mathrm{C}\right)$ for 30 minutes. The contents of wells was aspirated and washed 4 times with wash buffer $(350 \mu 1$ per well). The plate was inverted and tapped firmly on absorbent paper. Then $100 \mu \mathrm{l}$ of Conjugate reagent added into the appropriate wells. Then the plate was covered with lid and incubated at room temperature $\left(22-27^{\circ} \mathrm{C}\right)$ for 30 minutes. The procedure was repeated as in previous. Then $100 \mu 1$ of Substrate reagent was added into the appropriate wells and the plate was covered with lid and incubated at room temperature $\left(22-27^{\circ} \mathrm{C}\right)$ for 15 minutes. Then $100 \mu \mathrm{l}$ of Stop solution was added to appropriate wells to stop reaction. The ELISA plate was read by the microtiter plate reader in the Kazi Farms Poultry Laboratory, Gazipur and recorded the absorbance of controls and samples by reading at $405 \mathrm{~nm}$. For the test result to be valid the mean negative control absorbance should read below 0.30 and the difference between the mean negative control and the mean positive control should be greater than 0.15 . The AIV positive control has been carefully standardized to represent significant amounts of antibody to AIV in duck serum. The relative amounts of antibodies in duck samples can then be calculated by reference to the positive control. This relationship is expressed as $\mathrm{S} / \mathrm{P}$ ratio (Sample to Positive Ratio). Samples with an $\mathrm{S} / \mathrm{P}$ of 0.35 or greater contain anti-AIV antibodies were considered positive.

Calculation of $\mathrm{S} / \mathrm{P}$ ratio

Mean of Test Sample - Mean of negative control

$\overline{\text { Mean of Positive control - Mean of negative control }}=\mathrm{S} / \mathrm{P}$

\section{Calculation of antibody titer}

The following equation relates the S/P of a sample at a 1:500 dilution to an end point titer.

$\log _{10}$ Titer $=1.0 * \log (\mathrm{SP})+3.156$

Antilog $=$ Titer

S/P value

0.449 or less

\section{Titer Range}

0.500 or greater

667 or less

Antibody status

Negative

668 or greater

Positive

Rapid detection of AI type A virus from suspected duck

At first all components of Anigen Rapid AIV Ag test kit manufactured by BioNote, Inc. Korea and specimen were allowed to room temperature prior to testing. The test device was removed from foil pouch and placed it on a flat, dry surface. Then the swab was inserted into the specimen tube containing $1 \mathrm{ml}$ of assay diluents and mixed thoroughly to extract the virus. Then four drops of sample was taken with disposable dropper and added into the sample whole slowly and drop by drop. As the test begins to work, a purple color band moved across the result window into the center of the test device showed that the test is working properly; this band is the control band. The right section of the result window indicated the test results. The presence of only one band ("C") within the result window indicated a negative result. The presence of two color bands ("T" and "C") within the result window, no matter which band appears first indicated a positive result

\section{Results and Discussion}

(A) iELISA antibody titer level determination from collected sera samples

Collectively, $86.67 \%$ of the sera samples were positive for antibody by iELISA (Table 1). 
Table 1: Results of antibody titer of AIV from collected samples

\begin{tabular}{|c|c|c|c|c|c|c|}
\hline $\begin{array}{l}\text { SL. } \\
\text { No. }\end{array}$ & Farms with area & Groups & $\begin{array}{c}\text { Age of duck } \\
\text { (month) }\end{array}$ & No. of samples & $\begin{array}{c}\text { No. of Positive } \\
\text { titer }\end{array}$ & $\begin{array}{c}\% \text { of positive } \\
\text { cases }\end{array}$ \\
\hline 01. & Jamlur Duck Farm, Satasi, Maska, Netrokona & A & $3-4$ & 18 & 12 & $66.67 \%$ \\
\hline 02. & Habibur Duck Farm, Jalalpur, Kandiuda, Netrokona & $\mathrm{B}$ & $5-6$ & 18 & 14 & $77.77 \%$ \\
\hline 03. & Bokul Duck Farm, Mijafforpur, Netrokona & $\mathrm{C}$ & $7-8$ & 18 & 16 & $88.88 \%$ \\
\hline 04. & Ratan Duck Farm, Durgapur, Nowpara, Netrokona & $\mathrm{D}$ & $9-10$ & 18 & 18 & $100 \%$ \\
\hline \multirow[t]{2}{*}{05.} & Manik Duck Farm, Rajibpur, Kandiura, Netrokona & $\mathrm{E}$ & $\geq 11$ & 18 & 18 & $100 \%$ \\
\hline & Total & & & 90 & 78 & $86.67 \%$ \\
\hline
\end{tabular}

Detection of antibody titer level from Group A

The results of the sera collected from 3-4 month of aged birds showed that highest titer was 1428 and the lowest titer 256 and

Table 2: Serum antibody titer of AIV suspected field sera samples from Group A

\begin{tabular}{|c|c|c|c|c|c|c|c|}
\hline $\begin{array}{c}\text { Name of farm and } \\
\text { area }\end{array}$ & $\begin{array}{c}\text { Age of the } \\
\text { Duck (month) }\end{array}$ & $\begin{array}{c}\text { Sample } \\
\text { No. }\end{array}$ & $\begin{array}{c}\text { Antibody } \\
\text { titer }\end{array}$ & Interpretation & Titer range & Mean titer & $\begin{array}{c}\text { Percent } \\
\text { Positive (\%) }\end{array}$ \\
\hline \multirow{18}{*}{$\begin{array}{c}\text { Jamrul duck farm, } \\
\text { Satasi, Maska, } \\
\text { Netrokona }\end{array}$} & \multirow{18}{*}{$3-4$} & 01 & 1383 & + & \multirow{18}{*}{$256-1428$} & \multirow{18}{*}{906.3} & \multirow{18}{*}{$66.66 \%$} \\
\hline & & 02 & 1307 & + & & & \\
\hline & & 03 & 927 & + & & & \\
\hline & & 04 & 460 & - & & & \\
\hline & & 05 & 887 & + & & & \\
\hline & & 06 & 1147 & + & & & \\
\hline & & 07 & 1428 & + & & & \\
\hline & & 08 & 1388 & + & & & \\
\hline & & 09 & 887 & + & & & \\
\hline & & 10 & 359 & - & & & \\
\hline & & 11 & 778 & + & & & \\
\hline & & 12 & 966 & + & & & \\
\hline & & 13 & 523 & - & & & \\
\hline & & 14 & 460 & - & & & \\
\hline & & 15 & 1355 & + & & & \\
\hline & & 16 & 256 & - & & & \\
\hline & & 17 & 391 & - & & & \\
\hline & & 18 & 1413 & + & & & \\
\hline Legend: & $\begin{array}{l}\text { range } \\
\text { or less } \\
\text { or greater }\end{array}$ & $\begin{array}{l}\text { Antibody } \\
\text { Negative } \\
\text { Positive }\end{array}$ & tus & & & & \\
\hline
\end{tabular}

Detection of antibody titer level from Group B

The results of the sera collected from 5-6 month of aged birds showed that highest titer was 1675 and the lowest titer 451 and

Table 3: Serum antibody titer of AIV suspected field sera samples from Group B

\begin{tabular}{|c|c|c|c|c|c|c|c|}
\hline $\begin{array}{l}\text { Name of farm and } \\
\text { area } \\
\end{array}$ & $\begin{array}{c}\text { Age of the } \\
\text { Duck (month) }\end{array}$ & $\begin{array}{c}\text { Sample } \\
\text { No. } \\
\end{array}$ & $\begin{array}{c}\text { Antibody } \\
\text { titer }\end{array}$ & Interpretation & Titer range & Mean titer & $\begin{array}{c}\text { Percent } \\
\text { Positive }(\%) \\
\end{array}$ \\
\hline \multirow{18}{*}{$\begin{array}{l}\text { Habibur duck farm, } \\
\text { Jalalpur, kandiuda, } \\
\text { Netrokona }\end{array}$} & \multirow{18}{*}{$5-6$} & 01 & 763 & + & \multirow{18}{*}{$451-1675$} & \multirow{18}{*}{1083.6} & \multirow{18}{*}{$78 \%$} \\
\hline & & 02 & 686 & + & & & \\
\hline & & 03 & 597 & - & & & \\
\hline & & 04 & 1618 & + & & & \\
\hline & & 05 & 451 & - & & & \\
\hline & & 06 & 999 & + & & & \\
\hline & & 07 & 1533 & + & & & \\
\hline & & 08 & 1675 & + & & & \\
\hline & & 09 & 1272 & + & & & \\
\hline & & 10 & 1349 & + & & & \\
\hline & & 11 & 468 & - & & & \\
\hline & & 12 & 1360 & + & & & \\
\hline & & 13 & 1212 & + & & & \\
\hline & & 14 & 1174 & + & & & \\
\hline & & 15 & 1323 & + & & & \\
\hline & & 16 & 649 & - & & & \\
\hline & & 17 & 1549 & + & & & \\
\hline & & 18 & 827 & + & & & \\
\hline Legend: & $\begin{array}{l}\text { range } \\
\text { or less } \\
\text { or greater }\end{array}$ & $\begin{array}{l}\text { Antibody } \\
\text { Negative } \\
\text { Positive }\end{array}$ & & & & & \\
\hline
\end{tabular}

the mean titer was 1083.6. The detailed results are shown in Table 3 . the mean titer was 906.3. The detailed results are shown in Table 2 .

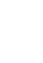


Detection of antibody titer level from Group C

The results of the sera collected from 7-8 month of aged birds showed that highest titer was 1857 and the lowest titer 578 and the mean titer was 1285.5. The detailed results are shown in Table 4

Table 4: Serum antibody titer of AIV suspected field sera samples from Group C

\begin{tabular}{|c|c|c|c|c|c|c|c|}
\hline $\begin{array}{c}\text { Name of farm and } \\
\text { area }\end{array}$ & $\begin{array}{c}\text { Age of the } \\
\text { Duck (month) }\end{array}$ & $\begin{array}{c}\text { Sample } \\
\text { No. }\end{array}$ & $\begin{array}{l}\text { Antibody } \\
\text { titer }\end{array}$ & Interpretation & Titer range & Mean titer & $\begin{array}{c}\text { Percent } \\
\text { Positive }(\%)\end{array}$ \\
\hline \multirow{18}{*}{$\begin{array}{l}\text { Bokul duck farm, } \\
\text { Mojaffarpur, } \\
\text { Netrokona }\end{array}$} & \multirow{18}{*}{$7-8$} & 01 & 1297 & + & \multirow{18}{*}{$578-1857$} & \multirow{18}{*}{1285.5} & \multirow{18}{*}{$88.9 \%$} \\
\hline & & 02 & 773 & + & & & \\
\hline & & 03 & 1574 & + & & & \\
\hline & & 04 & 1857 & + & & & \\
\hline & & 05 & 1097 & + & & & \\
\hline & & 06 & 1145 & + & & & \\
\hline & & 07 & 1041 & + & & & \\
\hline & & 08 & 610 & - & & & \\
\hline & & 09 & 1265 & + & & & \\
\hline & & 10 & 1686 & + & & & \\
\hline & & 11 & 1696 & + & & & \\
\hline & & 12 & 578 & - & & & \\
\hline & & 13 & 1618 & + & & & \\
\hline & & 14 & 1423 & + & & & \\
\hline & & 15 & 1338 & + & & & \\
\hline & & 16 & 1449 & + & & & \\
\hline & & 17 & 1765 & + & & & \\
\hline & & 18 & 927 & + & & & \\
\hline Legend: & $\begin{array}{l}\text { range } \\
\text { or less } \\
\text { or greater }\end{array}$ & $\begin{array}{l}\text { Antibody } \\
\text { Negative } \\
\text { Positive }\end{array}$ & tus & & & & \\
\hline
\end{tabular}

Detection of antibody titer level from Group D

The results of the sera collected from 9-10 month of aged birds showed that highest titer was 1971 and the lowest titer 927 and the mean titer was 1571.5. The detailed results are shown in Table 5.

Table 5: Serum antibody titer of AIV suspected field sera samples from Group D

\begin{tabular}{|c|c|c|c|c|c|c|c|}
\hline $\begin{array}{c}\text { Name of farm and } \\
\text { area }\end{array}$ & $\begin{array}{c}\text { Age of the } \\
\text { Duck (month) }\end{array}$ & $\begin{array}{l}\text { Sample } \\
\text { No. }\end{array}$ & $\begin{array}{l}\text { Antibody } \\
\text { titer }\end{array}$ & Interpretation & Titer range & Mean titer & $\begin{array}{c}\text { Percent } \\
\text { Positive }(\%)\end{array}$ \\
\hline \multirow{18}{*}{$\begin{array}{c}\text { Ratan duck farm, } \\
\text { Durgapur, Nowpara, } \\
\text { Netrokona }\end{array}$} & \multirow{18}{*}{$9-10$} & 01 & 1971 & + & \multirow{18}{*}{$927-1971$} & \multirow{18}{*}{1571.5} & \multirow{18}{*}{$100 \%$} \\
\hline & & 02 & 1378 & + & & & \\
\hline & & 03 & 1513 & + & & & \\
\hline & & 04 & 1749 & + & & & \\
\hline & & 05 & 1533 & + & & & \\
\hline & & 06 & 1696 & + & & & \\
\hline & & 07 & 1638 & + & & & \\
\hline & & 08 & 1618 & + & & & \\
\hline & & 09 & 1423 & + & & & \\
\hline & & 10 & 1323 & + & & & \\
\hline & & 11 & 1449 & + & & & \\
\hline & & 12 & 1678 & + & & & \\
\hline & & 13 & 1749 & + & & & \\
\hline & & 14 & 927 & + & & & \\
\hline & & 15 & 1223 & + & & & \\
\hline & & 16 & 1649 & + & & & \\
\hline & & 17 & 1843 & + & & & \\
\hline & & 18 & 1927 & + & & & \\
\hline Legend: & $\begin{array}{l}\text { range } \\
\text { or less }\end{array}$ & $\begin{array}{l}\text { Antibody } \\
\text { Negative }\end{array}$ & & & & & \\
\hline
\end{tabular}


668 or greater Positive

Detection of antibody titer level from Group $\mathrm{E}$

The results of the sera collected from 9-10 month of aged birds showed that highest titer was 2323 and the lowest titer 1423 and the mean titer was 1813.7. The detailed results are shown in Table 6.

Table 6: Serum antibody titer of AIV suspected field sera samples from Group E

\begin{tabular}{|c|c|c|c|c|c|c|c|}
\hline $\begin{array}{c}\text { Name of farm and } \\
\text { area }\end{array}$ & $\begin{array}{c}\text { Age of the } \\
\text { Duck (month) }\end{array}$ & $\begin{array}{l}\text { Sample } \\
\text { No. }\end{array}$ & $\begin{array}{l}\text { Antibody } \\
\text { titer }\end{array}$ & Interpretation & Titer range & $\begin{array}{c}\text { Mean } \\
\text { titer }\end{array}$ & $\begin{array}{c}\text { Percent } \\
\text { Positive }(\%)\end{array}$ \\
\hline \multirow{18}{*}{$\begin{array}{c}\text { Manik duck farm, } \\
\text { Rajibpur, kandiura, } \\
\text { Netrokona }\end{array}$} & \multirow{18}{*}{$\geq 11$} & 01 & 1649 & + & \multirow{18}{*}{$1423-2323$} & \multirow{18}{*}{1813.7} & \multirow{18}{*}{$100 \%$} \\
\hline & & 02 & 1849 & + & & & \\
\hline & & 03 & 1618 & + & & & \\
\hline & & 04 & 1423 & + & & & \\
\hline & & 05 & 2121 & + & & & \\
\hline & & 06 & 1997 & + & & & \\
\hline & & 07 & 2272 & + & & & \\
\hline & & 08 & 1618 & + & & & \\
\hline & & 09 & 1774 & + & & & \\
\hline & & 10 & 2323 & + & & & \\
\hline & & 11 & 1449 & + & & & \\
\hline & & 12 & 1678 & + & & & \\
\hline & & 13 & 1749 & + & & & \\
\hline & & 14 & 1927 & + & & & \\
\hline & & 15 & 1839 & + & & & \\
\hline & & 16 & 1686 & + & & & \\
\hline & & 17 & 1749 & + & & & \\
\hline & & 18 & 1927 & + & & & \\
\hline Legend: & $\begin{array}{l}\text { range } \\
\text { or less } \\
\text { or greater }\end{array}$ & $\begin{array}{l}\text { Antibod } \\
\text { Negative } \\
\text { Positive }\end{array}$ & atus & & & & \\
\hline
\end{tabular}

(B) Detection of AIV antigen from suspected field samples AIV was detected in only 1 sample out of five tested samples (Table 7) which indicated that $20 \%$ sample was positive whereas $10 \%$ sample was influenza-A positive by rapid diagnostic kit (Tsunetsugu et al, 2014).

Table 7: Results of rapid AIV antigen detection from collected samples

\begin{tabular}{|c|c|c|c|c|c|}
\hline $\begin{array}{c}\text { Name of the } \\
\text { farm and } \\
\text { area }\end{array}$ & $\begin{array}{c}\text { Age of } \\
\text { duck } \\
\text { (month) }\end{array}$ & $\begin{array}{c}\text { Sample } \\
\text { no. }\end{array}$ & $\begin{array}{c}\text { Name of } \\
\text { sample }\end{array}$ & Result & $\begin{array}{c}\text { Percent } \\
\text { positive } \\
(\%)\end{array}$ \\
\hline \multirow{5}{*}{$\begin{array}{l}\text { Manik } \\
\text { Poultry } \\
\text { Farm, } \\
\text { Rajibpur, } \\
\text { Kandiura, } \\
\text { Netrokona }\end{array}$} & \multirow{5}{*}{$\geq 11$} & 1 & Cloacal swab & _ & \multirow{5}{*}{$20 \%$} \\
\hline & & 2 & Tracheal swab & + & \\
\hline & & 3 & Tracheal swab & - & \\
\hline & & 4 & Cloacal swab & - & \\
\hline & & 5 & Tracheal swab & - & \\
\hline
\end{tabular}

The present study further revealed that a total $86.67 \%$ sere samples were positive for AI antibodies related to the findings of Wegdan $\mathrm{H}$ et al, 2007 (86.4\%) which observed on unvaccinated chicken and also to the findings of Khatun et al, 2013 (39.76\% ducks were sero-positive for avian influenza type A antibody) and Jurado et al, 2014 (65.3\% seroprevalance positive by ELISA). This results due to rearing of ducks under confinedoutdoor, scavenging system in the study area where ducks allowed to scavenge in village with domestic chicken and pig in the yard, crop field, low waterland (haowr) where wild ducks and different water fowls live together and share the same field. Therefore, duck acts as mixing vessels and reservoir host of influenza A virus (Yu et al, 2008; Patin et al, 2007) and normally AIVs persist up to four weeks in individual duck (Webster et al 1992). These factors might contribute in natural infection to the native duck and prevalence of influenza $\mathrm{A}$ in Netrokona district is higher.

In the present research work the highest mean titer was found in group $\mathrm{E}$ as 1813.7 of $\geq 11$ month of aged duck. The chronological increase of mean antibody titer 906.3, 1083.6, 1285.5, 1571.5 and 1813.7 at $3-4,5-6,7-8,9-10$ and $\geq 11$ month of age respectively due to infection with AIV and persistent of the agent for longer period of time. The other contributing factors might be poor biosecurity, mutation of low pathogenic avian influenza strain, lack of surveillance activity, traditional free-grazing duck husbandry and apparently healthy duck can play a vital role in AIV transmission.

\section{Conclusion}

Bangladesh was considered as a high-risk country for infection with highly pathogenic avian influenza since the outbreak in early 2006 in the neighboring countries like India and Myanmar with whom Bangladesh shares along border. Moreover during the winter season the domestic ducks might get AIV from migratory waterfowls and acts as a natural reservoir of AIV without showing clinical disease. From the findings of the present research AIV antibodies were successfully detected from the field outbreak through commercially AIV antibody test kit (ELISA kit) and the virus induced a significant antibody titer indicated that the affecting virus was absolutely AIV. The findings indicated that the present isolates might be evolved from reservoir ducks and excreted through feces and transmission occurred by fecaloral route and further mutation of the virus occurred which is alarming for public health and veterinary profession. Therefore ducks and poultry farms of this region should be monitored regularly for testing and also strict bio-security measures should be maintained. Lastly it can be concluded this finding is of particular importance to duck-producing region of the country for future studies of AIVs prevalence affected by HPAI.

\section{References}

Ahmed SS, Ersboll AK, Biswas PK, Christensen JP, Hannan AS, Toft N: Ecological determinants of highly pathogenic avian influenza (H5N1) outbreaks in Bangladesh. PLoS One 2012, 7(3): e33938

Alexander, D. J. 1982. Avian influenza: Recent developments. Vet. Bull. 52:341-359.

Alexander, D.J., 1995. The epidemiology and control of avian influenza and Newcastle disease. J. Comp. Pathol.112, 105126. 
Alexander, D.J., Brown, I.H., 2000. Recent zoonoses caused by influenza A viruses. Rev. Sci. Tech. 19, 197-225.

Asifuddin, (2013). A Study on Highly Pathogenic Avian Influenza in Bangladesh, Posted in Featured Article, June 8, 2013.

Henning, J.; Wibawa, H.; Morton, J.; Usman, T.B.; Junaidi, A. and Meers, J. 2010. Scavenging ducks and transmission of highly pathogenic avian influenza, Java, Indonesia. Emerg Infect Dis. 16(8): 1244-50.

Islam, M. R. and Giasuddin, M. 2007. Highly Pathogenic Avian Influenza Global situation and Bangladesh. $5^{\text {th }}$ International Poultry show and Seminar, WPSA-BB, 1-3 March 2007, Dhaka, Bangladesh.

Jurado, T.E.; Napp, S.; Gómez, P.J.; Fernández, M, M.; Jaén, T, J.; Arenas, A. and García, BI. 2014. Surveillance of influenza viruses in waterfowl used as decoys in andalusia, Spain. PLoS One. 9(6): e98890.

Khatun, A.; Giasuddin, M.; Islam, K.M.;Khanom,S.; Samad, M.A.; Islam, M.R.; Noor, M.; Bhuiyan, J.U.; Kim, W.I.; Eo, S.K.; and Rahman, M.M. 2013. Surveillance of avian influenza virus type $\mathrm{A}$ in semi-scavenging ducks in Bangladesh. BMC vet Res. 9:196. doi: 10.1186/1746-61489-196.

Lupiani, B., Reddy, S.M. 2009. The history of avian influenza. Comp Immunol Microbiol, Infect Dis, 32 (4), 311-323.

Pantin, J, MJ. and Swayne, DE. 2007. Pathobiology of Asian highly pathogenic avian influenza $\mathrm{H} 5 \mathrm{~N} 1$ virus infections in ducks. Avian Dis. 51(1):250-9.

Saif, Y.M., Barnes, H. J., Glisson, J. R., Fady, A. M. McDougald, L. R. and Swayne 2003. Disease of Poultry (11 ${ }^{\text {th }}$ Edition). Pp.135-160.

Tsunetsugu,Y, Y.; Nishimura, K.; Misawa, S.; Kobayashi, I, M.; Takahashi ,H.; Takayama, I.; Ohnishi, K.; Itamura, S.; Nguyen, HL.; Le, MT.; Dang, G.T.; Nguyen, LT.; Tashiro, M. and Kageyama ,T.(2014). Development of a sensitive novel diagnostic kit for the highly pathogenic avian influenza A (H5N1) virus. BMC Infect Dis. 14(1):362.

Webster RG, Bean WJ, Gorman OT, Chambers TM, Kawaoka Y: Evolution and ecology of influenza A virus. Microbiol Rev 1992, 56(1): 152-179.

Webster, R.G. (2004). Wet markets-a continuing source of severe acute respiratory syndrome and influenza. Lancet 363, 234236.

Wegdan, H.; Ali.; Kheir.; S,A.M. and Ballal, A. (2007). Serological Survey of Type A Avian Influenza Antibody in Chicken Sera in Sudan Using Indirect ELISA. Research Journal of Animal and Veterinary Sciences, 2: 12-14.

Yu, Y.; Kikuyasu, N.; Masatoshi, O.; Ayako, M.; Manabu ,Y. and Masaji, M. 2008. Detecting Avian Influenza Virus (H5N1) in Domestic Duck Feathers. Emerg Infect Dis. 14(10): 1671-1672. 